\title{
Dengue in the WHO Eastern Mediterranean Region: challenges to understand its epidemiology
}

\author{
Abdulla Salem Bin Ghouth* \\ Department of Community Medicine, Hadramout University Malaria Control Program, Hadramout, Yemen
}

Dengue is the most rapidly spreading mosquito-borne viral disease in the world. In the last 50 years, incidence has increased 30 -fold with increasing geographic expansion to new countries and, in the present decade, from urban to rural settings [1]. An estimated 50 million dengue infections occur annually and approximately 2.5 billion people live in dengue endemic countries [2].

Outbreaks of dengue have been documented in the Eastern Mediterranean Region possibly as early as 1799 in Egypt [3]. The frequency of reported outbreaks continue to increase, with outbreaks for example in Sudan (1985, DEN-1 and -2) [4] and in Djibouti (1991, DEN-2) [5]. Recent outbreaks of suspected dengue have been recorded in Saudi Arabia, Sudan and Yemen, 2005-2006 [3]. Yemen is also affected by the increasing frequency and geographic spread of epidemic dengue, and the number of cases has risen since the major DEN-3 epidemic that occurred in the western al-Hudeidah governorate in 2005. In 2008 dengue affected the southern province of Shabwa. Since the first case of DHF died in Jeddah in 1993, Saudi Arabia has reported three major epidemics: a DEN-2 epidemic in 1994 with 469 cases of dengue, a DEN-1 epidemic in 2006 with 1269 cases of dengue. ${ }^{1}$ In Somalia infections of DENV-1, DENV-2, DENV-3 and co-infections of DENV-1/2 and DENV-2/3 sero-types were identified in the Magdieshou outbreak in 2011 [6] (Figure 1) Pakistan may be represent the highest burden of dengue in EMRO region, since 2006, dengue epidemics have occurred every year and the range has extended to most cities in Pakistan. Dengue now affects thousands of people and has caused hundreds of deaths. It has become a major health problem in Pakistan, and it is likely to become an even greater health problem in the coming years [7].

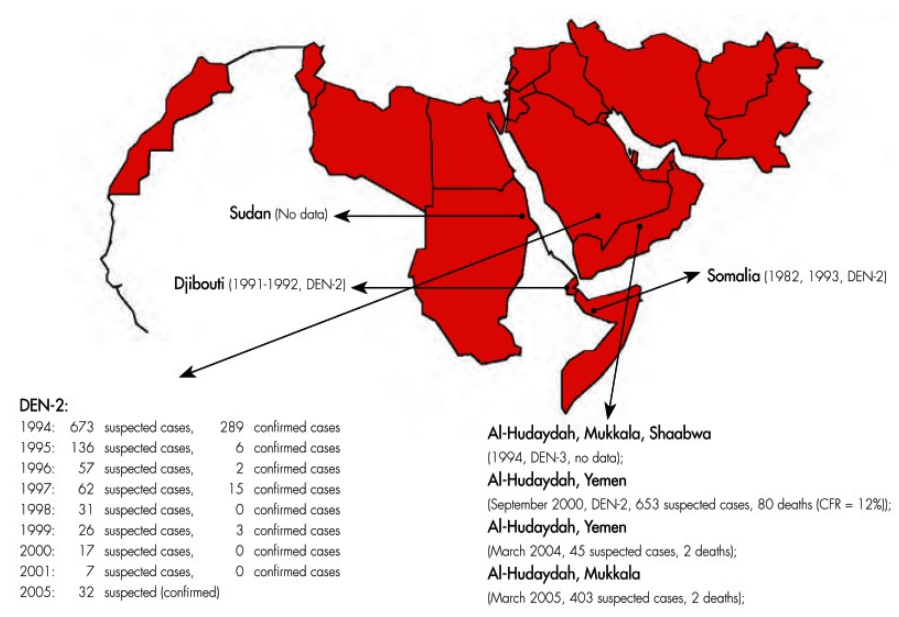

Figure 1. Outbreaks of dengue fever in the WHO Eastern Mediterranean Region, 1994 2005 [9].
In the Middle East and North Africa, the epidemiology of dengue remains poorly characterized despite increasing reports of outbreaks and transmission in new areas. In order to understand the evidence supporting the epidemiology of this virus in the region and the areas in need of further research [8] several studies condcluded challenges facing better understanding dengue epidemiology in MENA region; Understanding the epidemiology of DENV in the MENA represents an ongoing challenge for multiple reasons [9]. Inadequate human and vector surveillance, non-reporting of illness syndromes, and poor diagnostic capacity limit DENV detection in many countries, resulting in delays in outbreak recognition and sparse data with which to estimate disease burden and infection rates [10-12]. [Case series, outbreak reports, and national notification reports, which contribute much to the epidemiologic knowledge of DENV, may also contain bias in reflecting only those areas with sufficient capacity to detect and report DENV when it occurs. Moreover, clinical diagnosis of DENV infection in the absence of laboratory confirmation is often unreliable [10,13-16]. Cross-sectional serologic surveys for DENV exposure have the potential to shed light on the broader population burden of DENV without these biases. However, serologic cross-reactions among antibody-based assays for flaviviruses can limit the reliability of such studies in the absence of confirmatory testing, though the latter is difficult to perform and often unavailable $[17,18]$.

\section{References}

1. WHO (2009) Dengue: Guidelines for Diagnosis, Treatment, Prevention and Control: New Edition, Geneva.

2. WHO (2008) Dengue and dengue. World Health Organization, Geneva.

3. WHO/EMRO (2005) Regional Office for the Eastern Mediterranean; Division of Communicable Disease Control. World Health Organization, Newsletter L: 7-8.

4. Hyams KC (1986) Evaluation of febrile patients in Port Sudan, Sudan: isolation of dengue virus. American Journal of Tropical Medicine and Hygiene 35:860-865.

5. Rodier GR, Gubler DJ, Cope SE, Cropp CB, Soliman AK, et al. (1996) Epidemic dengue 2 in the city of Djibouti 1991-1992. Trans R Soc Trop Med Hyg 90: 237-240. [Crossref]

6. Kyobe H, Bosa HK, Montgomery JM, Kimuli I, Lutwama J et al. (2014) Dengue fever outbreak in Mogadishu, Somalia 2011: Co-circulation of three dengue virus serotypes. International Journal of Infectious Diseases 21(S1): 3.

7. Rasheed SB, Butlin RK, Boots M (2013) A review of dengue as an emerging disease in Pakistan. Public Health 127: 11-17. [Crossref]

Correspondence to: Abdulla Salem Bin Ghouth, Department of Community Medicine, Hadramout University Malaria Control Program, Hadramout, Yemen, Tel: +967 734167 199; E-mail: abinghouth2007@yahoo.com

Received: March 21, 2018; Accepted: April 21, 2018; Published: April 24, 2018 
8. Humphrey JM, Cleton NB, Reusken CBEM, Glesby MJ, Koopmans MPG, et al. (2016) Dengue in the Middle East and North Africa: A Systematic Review. PLoS Negl Trop Dis 10: e0005194.

9. WHO (2006) World Health Organization. Neglected tropical diseases: an emerging public health problem in the Eastern Mediterranean Region. 54th Regional Committe meeting, Eastern Mediterranean Region. Cairo, Egypt.

10. Malik MR, Mnzava A, Mohareb E, Zayed A, Al Kohlani A, et al. (2014) Chikungunya outbreak in Al-Hudaydah, Yemen, 2011: epidemiological characterization and key lessons learned for early detection and control. J Epidemiol Glob Health 4: 203-211.

11. Chan EH, Brewer TF, Madoff LC, Pollack MP, Sonricker AL, et al. (2010) Global capacity for emerging infectious disease detection. Proceedings of the National Academy of Sciences of the United States of America 107: 21701-21706.

12. Aghaie A, Aaskov J, Chinikar S, Niedrig M, Banazadeh S, et al. (2014) Frequency of dengue virus infection in blood donors in Sistan and Baluchestan province in Iran. Transfus Apher Sci 50: 59-62.
13. Elduma AH, Osman WM (2014) Dengue and hepatitis E virus infection in pregnant women in Eastern Sudan, a challenge for diagnosis in an endemic area. Pan Afr Med $J$ 19: 391.

14. Burt FJ, Rolph MS, Rulli NE, Mahalingam S, Heise MT (2012) Chikungunya: a reemerging virus. Lancet 379: 662-671.

15. Ali F, Saleem T, Khalid U, Mehmood SF, Jamil B (2010) Crimean-congo hemorrhagic fever in a dengue-endemic region: Lessons for the future. J Infect Dev Ctries 4: 459-463.

16. Watts DM, El-Tigani A, Botros BAM, Salib AW, Olson JG, et al. (1994) Arthropodborne viral infections associated with a fever outbreak in the Northern Province of Sudan. J Trop Med Hyg 97: 228-230.

17. Bargaoui R, Lecollinet S, Lancelot R (2013) Mapping the Serological Prevalence Rate of West Nile fever in Equids, Tunisia. Transbound Emerg Dis. 62: 55-66.

18. Ben Hassine T, De Massis F, Calistri P, Savini G, BelHaj Mohamed B, et al. (2014) First Detection of Co-circulation of West Nile and Usutu Viruses in Equids in the South-west of Tunisia. Transbound Emerg Dis 61: 385-389.

Copyright: $@ 2018$ Ghouth ASB. This is an open-access article distributed under the terms of the Creative Commons Attribution License, which permits unrestricted use, distribution, and reproduction in any medium, provided the original author and source are credited. 